\title{
THE EFFECT OF LOCAL ANESTHETICS ON TEAR PRODUCTION
}

\author{
BY \\ *NWAJI, E. C. S. AND BARRAH, G. O. \\ * DEPARTMENT OF OPTOMETRY, ABIA STATE UNIVERSITY, \\ UTURU, ABIA STATE, NIGERIA \\ Email:nwajiecs2001@yahoo.co.uk \\ *corresponding author
}

\begin{abstract}
Local anesthetics act on any part of the nervous system and on every type of nerve and fibre. Different sensations are lost according to the size of the axon serving them. Lignocaine due to its moderate properties is one of the most versatile agents in anesthesia and as such is often used by optometrists and ophthalmologists alike in different clinical procedures. Tear production using Schirmer's technique was measure before and after the instillation of a local anesthetic (Lignocaine 2\%) in fifty (50) subjects of both male and female within the age range 18 -35 years. Results from data collected showed that Lignocaine caused a slight reduction in tear production; with a mean percentage reduction of $29.06 \%$. Statistical analysis also revealed the effect of lignocaine on tear production to be significant $(\mathrm{P}<0.05)$.
\end{abstract}

KEYWORDS: Tear production, Lignocaine, Local anesthetic, Schirmer's test.

\section{INTRODUCTION}

Anesthetics are drugs which bring about the state of anesthesia and anesthesia is a measure, which produces insensitivity to external expression or a reversible lack of awareness which can be general or local ${ }^{1}$. General anesthetics act on all parts of the body while local anesthetics act on some parts of the body or a part of the body.

When applied in an effective concentration to nerve tissue, local anesthetics reversibly block the conduction of impulses through nerve fibres. The primary action is to prevent impulses conduction. However, they will also block motor nerves in higher concentrations than are normally obtained by topical instillation. Examples of Local anesthetics include amethocaine, Lignocaine and oxbuprocaine ${ }^{2}$.

As ophthalmic surgeries are performed with increasing frequency in outpatient' facilities, local anesthesia/sedation is a reasonable alternative to general anesthesia for selected patients with open globe injuries.

Systemic administration of diuretics causes a decrease in tear flow. Also, mucominetics have been found to increase tear break-up-time (TBUT) and decrease out flow of tear whereas gentamycin ointments may decrease both TBUT and outflow ${ }^{2}$.

This study was aimed at determining the actual effect of anesthetic (lignocaine) on tear production. It also compared the quantity of tear production before ad after the instillation of the local anesthetic. The result of this research will enable ocular health workers to know the exact effect of lignocaine on tear production and take necessary precaution on its use.

\section{MATERIALS AND METHODS}

A total of 50 healthy volunteers of both sexes within the age range 18-35 years were used for the study. The research was carried out in the Optometry clinic of Abia State University.

The case history was taken for each subject and the subjects were confirmed to be free of any drug use capable of affecting the autonomic nervous system. Thorough eye examination was conducted on each subject to rule out any form of ocular pathology or debilitating disease that could influence glandular secretion.

The instrument of research will be direct ocular examination and the materials used include pen light, ophthalmoscope, P.D. rule, stop clock, tear strips (Wilson Ophthalmic tear flow sterile tear strips), cotton wool (wisps) and local anesthetic (lignocaine $2 \%$ by Shreecem Pharmaceuticals PVT. Ltd, bath No: L-030; expiry date: November 2007).

The measurement of the tear production was carried out using the tear strips. This was achieved by folding the tear strip $5 \mathrm{~mm}$ at one end, which was inserted at the junction of the middle and outer third 
of the lower lid. The subject was asked to keep the eyes open and blink as necessary after two minutes, the tear strip was removed and the amount of wetting noted from the calibrated tear strips.

The length of the moistened area was recorded indicating normal tear production for the given subject in millimeters. Individuals with tear production values of $12 \mathrm{~mm}$ and below were contraindicated for this research as such values are considered as deficient tear production values and a probability of the presence of dry eye.

The local anesthetic (lignocaine 2\%) was then topically instilled by everting the lower-lid of one eye and two drops instilled in the inferior cul-desac of the same eye. The test was then repeated two minutes after the instillation of the local anesthetic to allow for elapsing of the stinging sensation/irritation associated with topical anesthetics and the value for the tear production after anesthetic was recorded. Ten minutes after, the test was repeated and the value was recorded as described above.

Values for tear production collected were grouped into classes with intervals of $2 \mathrm{~mm}$ for each class. Analysis of data was carried out using frequencies, mean, percentages and two-tailed Ztest at $95 \%$ confidence level to evaluate the significance of the effect of the anesthetic on tear production.

\section{RESULT}

The data of tear production were obtained from 50 subjects of both sexes and all within the age range of 18-35 years. Readings were taken of tear production before the instillation of a local anesthetic (lignocaine) and after the instillation of anesthetic.

From table 1, it was noticed that the total mean tear production reduced two minutes post instillation of lignocaine $(189.54 \mathrm{~mm}$ to $170.59 \mathrm{~mm})$. The reduction in tear production was transient as the reading went back to near baseline ten minutes post instillation of lignocaine. Z-test analysis showed that the effect of lignocaine on tear production was statistically significant $\left(\mathrm{Z}_{\text {cal }}\right.$ was 5.82 which did not lie within \pm 1.96 ).

Mean reduction in tear production 2 minutes after instillation of anesthetic (lignocaine) was about $7.56 \mathrm{~mm}$ with a percentage reduction of $29.06 \%$ approximately. 10 minutes post instillation of lignocaine; mean reduction of tear production was $1.74 \mathrm{~mm}$ with percentage reduction tear production of approximately $6.69 \%$, thus returning towards baseline value (table 2).

Normal tear production among research population decreased with increase in age, from $29.2 \mathrm{~mm}$ for age group of $18-20$ years to $12.0 \mathrm{~mm}$ for age group of 33-35. The same pattern was observed for the induced effect of lignocaine on tear production (table 3 ).

\section{DISCUSSION}

The study involved a total of 50 volunteers of which 21 were males while 29 were females all with age range of 18-35years. Inference drawn from table 3 showed a gradual reduction in the normal tear production with increase in age. The induced effect of lignocaine was found to be more in younger people than in older ones.

Analysis of data showed values from mean tear production before anesthesia to be $26.02 \pm 6.32 \mathrm{~mm}$, while the mean tear production after anesthesia was $18.46 \pm 6.51 \mathrm{~mm}$ (table 2).

These major findings go a long way to confirm that local anesthetics measure only basic secretion thus reducing normal tear production/secretion, which is both reflex and basic ${ }^{3}$. This could be attributed to the fact that local anesthetics have an adrenergic potentiating effects and because lacrimal fluid receive a preganglionic parasympathetic supply from lacrimal muscles and leave the facial nerve to synapse in the sphenopalatine ganglion before running into the lacrimal gland, it stimulation produces secretion of tears (reflex secretor) ${ }^{4}$.

Statistical analysis of the data obtained from 50 subjects showed that local anesthetics (lignocaine) cause a significant $(\mathrm{P}>0.05)$ reduction in normal tear production. $\mathrm{Z}_{\text {cal }}$ was 5.82 , which did not lie within \pm 1.96 . Total mean tear flow value reduced from $189.5 \mathrm{~mm}$ to $170.59 \mathrm{~mm}$ before and after instillation respectively and causing a percentage decrease of approximately $30.45 \%, 2$ minutes after anesthesia. Sex has no significant relationship with normal tear reduction (table 1). There was a slight decrease in normal tear production with increase in age (table 3 ).

The use of lignocaine as local anesthesia for ocular tissue can be said to be safe, but practitioners are advised to screen patients for dry eye syndrome (where necessary) before its use. 
TABLE 1: SUMMARY OF MEAN TEAR PRODUCTION BEFORE AND AFTER ANESTHETIC

\begin{tabular}{|l|l|l|l|}
\hline $\begin{array}{l}\text { Class interval for } \\
\text { tear production } \\
(\mathbf{m m})\end{array}$ & $\begin{array}{l}\text { Mean tear } \\
\text { production before } \\
\text { anesthetic }(\mathbf{m m})\end{array}$ & $\begin{array}{l}\text { Mean tear production } \\
\mathbf{2} \text { mins after anesthetic } \\
(\mathbf{m m})\end{array}$ & $\begin{array}{l}\text { Mean tear production } \\
\mathbf{1 0} \text { mins after } \\
\text { anesthetic }(\mathbf{m m})\end{array}$ \\
\hline $6-8$ & - & 7.67 & - \\
\hline $9-11$ & - & 9.67 & - \\
\hline $12-14$ & 13.67 & 13.00 & 12.80 \\
\hline $15-17$ & 15.50 & 15.64 & 16.33 \\
\hline $18-20$ & 19.25 & 18.86 & 19.60 \\
\hline $21-23$ & 22.60 & 22.00 & 22.50 \\
\hline $24-26$ & 24.80 & 25.50 & 25.08 \\
\hline $27-29$ & 28.08 & 28.25 & 27.88 \\
\hline $30-32$ & 30.86 & 30.00 & 30.67 \\
\hline $33-35$ & 34.78 & - & 34.00 \\
\hline & 5189.54 & $\Sigma 170.59$ & 2188.88 \\
\hline
\end{tabular}

TABLE 2: SUMMARY OF MEAN BASELINE AND MEAN INDUCED TEAR PRODUCTION DUE TO INSTILLATION OF LOCAL ANESTHETICS (MEAN BASE VALUE $=2602 \pm 6.32 \mathrm{MM}$ )

\begin{tabular}{|l|l|l|l|}
\hline $\begin{array}{l}\text { Class interval } \\
(\mathbf{m i n s})\end{array}$ & $\begin{array}{l}\text { Mean induced tear } \\
\text { production }(\mathbf{m m})\end{array}$ & $\begin{array}{l}\text { Mean change of tear } \\
\text { production }(\mathbf{m m})\end{array}$ & $\begin{array}{l}\text { Percentage } \\
\text { mean change }\end{array}$ \\
\hline 2 & $18.46 \pm 6.51$ & -7.56 & $29.06 \%$ \\
\hline 10 & $24.28 \pm 6.30$ & -1.74 & $6.69 \%$ \\
\hline
\end{tabular}

TABLE 3: THE MEAN TEAR FLOW ACCORDING TO AGE

\begin{tabular}{|l|l|l|l|l|}
\hline Age interval & Frequency & $\begin{array}{l}\text { Mean tear before } \\
\text { anesthesia }\end{array}$ & $\begin{array}{l}\text { Mean tear flow } \\
\text { after anesthesia }\end{array}$ & Mean Change \\
\hline $18-20$ & 10 & 29.2 & 19.9 & 24.55 \\
\hline $21-23$ & 16 & 27.3 & 20.3 & 23.80 \\
\hline $24-26$ & 10 & 28.2 & 22.2 & 25.20 \\
\hline $27-29$ & 5 & 23.0 & 14.8 & 18.90 \\
\hline $33-35$ & 3 & 12.0 & 11.0 & 11.50 \\
\hline
\end{tabular}

\section{R E F E R E N C E S}

1. Morris Fishbein, M. D. (1976): AnesthesiaThe New Illustrated Medical and Health Encyclopedia. Home Library Edn. H. S. Stuttman Co, New York, pp 87.

2. Igwe, S. A. (1999): Ocular Pharmacology. $2^{\text {nd }}$ Edn. Whytem Publishers, Okigwe, p 77.
3. Grosvenor, T. (2002): Primary Eye Care Optometry. $4^{\text {th }}$ Edn. Butterworth-Heinemann, p 649.

4. Strughold, H. (1953): The sensitivity of the cornea and conjunctiva of the human eye and the use of contact lenses. Am. J. Optom, 30:625-30. 